\title{
PERLINDUNGAN BURUH MIGRAN INDONESIA MELALUI PELATIHAN PARALEGAL DI BANYUMAS
}

\section{THE PROTECTION OF INDONESIAN MIGRANT WORKERS THROUGH PARALEGAL TRAINING IN BANYUMAS}

\author{
${ }^{1)}$ Sri Wijayanti, ${ }^{2)}$ Nurul Azizah Zayzda, ${ }^{3)}$ Tyas Retno Wulan, ${ }^{4)}$ Rani Hendriani \\ ${ }^{1,2}$ Jurusan Hubungan Internasional, ${ }^{3}$ Jurusan Sosiologi, \\ ${ }^{4}$ Fakultas Hukum, Universitas Jenderal Soedirman \\ Jl. HR. Bunyamin no 992, Purwokerto \\ email: yantietaslim@yahoo.com
}

\begin{abstract}
ABSTRAK
Berdasarkan hasil penelitian, website milik Paguyuban SERUNI yaitu http ://www.seruni.or.id/ dan Seruni Banyumas (akun di facebook) adalah media yang digunakan oleh Paguyuban Seruni Banyumas untuk membantu permasalahan BMI yang sedang bekerja di luar negeri. Melalui media tersebut, Paguyuban Seruni telah menerima 15 kasus pengaduan BMI. Sebanyak 6 kasus telah ditangani dan sisanya masih dalam proses penanganan. Salah satu kendala yang dihadapi oleh Paguyuban SERUNI adalah masih sedikitnya sumberdaya manusia yang memiliki pengetahuan tentang hukum dan rendahnya kemampuan untuk melakukan pendampingan kasus. Hal ini berakibat pada kasus untuk para BMI yang sedang mengalami permasalahan tidak maksimal untuk didampingi.Berdasarkan hal tersebut, pengabdian ini bertujuan untuk meningkatkan kualitas dan kuantitas sumberdaya manusia melalui pelatihan paralegal untuk buruh migran di Kabupaten Banyumas.Pelatihan ini menggunaka metode penyuluhan dan praktik pendampingan kasus.Dari pelatihan ini, para buruh migran semakin percaya diri untuk menjadi paralegal dan mampu untuk melakukan pendampingan kasus-kasus buruh migran.Mereka berhasil membentuk sebuah divisi advokasi bernama Paralegal Banyumas.
\end{abstract}

Kata kunci : Buruh Migran, Kasus, Paralegal, Pelatihan

\begin{abstract}
The Paguyuban Seruni's website in http :/www.seruni.or.id/ and Seruni's account on facebook are the tools that paguyuban Seruni used to help migrant worker's problem who are having stay overseas. Through it, Paguyuban Seruni have accepted 15 cases, 6 cases solved but the rest is going to be solved. The research also found that one of obstacles why the cases is going to be solved is lack of the human resources who do not have enough knowledge about law and low skills in dealing with how to handle the case. Consequently, the cases had not been well-handled.Based on that background, this public service focused on improving the quality and quantity of human resources through The Training of Paralegal for Protection of Migrant Workers in Banyumas. The method is used teaching and practicing theories to solve the cases. After they finished the training, there are become braver and braver as a paralegal, moreover they can do help to solve migrant worker's problems. They also succeeded to build an organization named Paralegal Banyumas.
\end{abstract}

Keyword : Case, Paralegal, Migrant Worker, Training

Submited : 30 Oktober $2017 \quad$ Revision : 27 Februari $2018 \quad$ Accepted : 5 Maret 2018

\section{PENDAHULUAN}

Kabuparen Banyumas adalah kabupaten yang banyak menempatkan Buruh Migran Indonesia (BMI) ke luar negeri. Berdasarkan data BNP2TKI, Banyumas menduduki peringkat 20 se Indonesia sebagai pengirim Buruh Migran Indonesia (BMI) ke luar negeri.Banyaknya 
jumlah BMI berkolerasi lurus dengan jumlah potensi permasalahanyang melibatkan BMI.Berbagai persoalan yang dialami oleh BMI seringkali disampaikan bukan kepada pemerintah, namun kepada BMI sendiri karena dianggap dapat mengerti tentang permasalahan mereka.

Salah satu yang ikut berperan aktif dan menerima pengaduan dari BMI asal Kabupaten Banyumas adalah Paguyuban SERUNI. Berdasarkan hasil penelitian, website milik Paguyuban SERUNI yaitu http ://www.seruni.or.id/ dan Seruni Banyumas (akun di facebook) adalah media yang digunakan oleh Paguyuban Seruni Banyumas untuk membantu permasalahan BMI yang sedang bekerja di luar negeri. Melalui media tersebut, Paguyuban Seruni telah menerima 15 kasus pengaduan BMI. Dengan memanfaatkan jejaring yang dimiliki oleh Paguyuban Seruni, sebanyak 6 kasus telah ditangani dan sisanya masih dalam proses penanganan (Wijayanti, 2016).

Berdasarkan pada temuan hasil penelitian yang dilakukan oleh Wijayanti, Zayzda dan Yamin (2015) Paguyuban SERUNI mengalami hambatan-hambatan dalam penanganan kasus. Hambatan tersebut antara lain : 1) masih rendahnya sumberdaya manusia di Paguyuban SERUNI yang memiliki pengetahuan tentang hukum, 2) rendahnya ketrampilan dan teknik-teknik yang diperlukan untuk melakukan pendampingan kasus., 3)keterbatasan sumberdaya manusia di Paguyuban SERUNI dimana hanya tiga orang anggota Paguyuban SERUNI yang bergelar sarjana hukum namun memiliki aktivitas lain di luar Paguyuban SERUNI. Sedangkan anggota Paguyuban SERUNI yang lainnya adalah para mantan BMI yang rata-rata lulus Sekolah Menengah Atas (SMA) dan Sekolah Menengah Pertama (SMP), 4) belum optimalnya jejaring yang dapat diakses oleh Paguyuban SERUNI untuk menyelesaikan kasus-kasus tersebut. Hambatan-hambatan tersebut menyebabkan pendampingan kasus untuk para BMI yang sedang mengalami permasalahan tidak maksimal.Sedangkan di satu sisi, Paguyuban Seruni menerima banyak permintaan untuk mendampingi kasus BMI, baik yang didalam negeri maupun yang di luar negeri.

Para mantan Buruh Migran Banyumas yang tergabung didalam Paguyuban SERUNI merepresentasikan salah satu bentuk civil society yakni grass root organization atau organisasi akar rumput. Civil society merupakan sebuah konsep dengan pemaknaan yang beragam.Dalam pengabdian dan artikel jurnal ini, makna civil society mengikuti pemahaman Antonio Gramsci, yakni ruang terjadinya perlawanan terhadap pemahaman ortodoks mengenai dunia serta perlawanan terhadap hegemoni kultural dan ideologis, salah satunya melalui kegiatan sukarelawan (voluntary associations) (Edward, 2004). Lebih jelasnya, perlawanan ini ditujukan kepada ide-ide kapitalisme sembari menawarkan transformasi sosial (Mayo, 2005).

Dengan demikian civil society mempunyai kekuatan untuk mengubah kehidupan masyarakat. Edward (2004) menjelaskan bahwa civil society memainkan 3 peran dalam perkembangan masyarakat, yakni peran ekonomi, peran sosial dan peran politik. Peran politik civil society merujuk kepada peran kontrol transparansi dan akuntabilitas pemerintah serta melalui upaya menjembatani masyarakat dengan pemerintah, terutama terkait hak-hak warga negara yang tidak terpenuhi.

Sementara itu bentuk nyata civil society meliputi semua kelompok yang bersifat sukarelawa seperti lembaga nonpemerintah, sarikat buruh, kelompok agama, kelompok bisnis, partai politik, gerakan sosial dan media independen (Edward, 2004). Kunreuther (2011) menjelaskan salah satu kategori kelompok civil society yakni organisasi akar rumput. 
Organisasi semacam ini merupakan kelompok orang yang memiliki kepentingan atau perhatian yang sama mengenai masalah sosial. Organisasi ini berbeda dari organisasi civil society lainnya karena karakter khas yang bersifat lokal, dan organisasi yang lebih demokratis dan tidak hirarkis.Organisasi akar rumput membantu menyelesaikan masalah dengan kegiatan berkumpul dan diskusi, lebih jauh lagi aktivitas yang membantu meningkatkan keterampilan dan kapasitas yang dibutuhkan dalam dunia ekonomi dan politik (Kunreuther, 2011).

Berdasarkan permasalahan yang dialami mitra, maka yang dilakukan Pengabdian kepada Masyarakat Berbasis Riset yaitu melakukan kegiatan Pelatihan Paralegal untuk Perlindungan Buruh Migran Indonesia. Paralegal adalah seseorang yang dididik dan dilatih untuk melakukan tugas-tugas hukum, tetapi tidak memenuhi syarat pengacara. Paralegal hanya berwenang untuk memberikan bantuan hukum dalam proses kasus yang diselesaikan dengan metode non-litigasi (Nusantara, 2016). Paralegal diperbolehkan untuk melakukan penyuluhan hukum.Keberadaan paralegal dari BMI ini sangat diperlukan untuk mendampingi dan mengawal kasus klien yang sedang berjuang mendapatkan keadilan

Pelatihan paralegal ini dengan demikian dimaksudkan untuk meningkatkan kapasitas organisasi akar rumput dalam hak ini kelompok mantan buruh migran di Banyumas dengan keterampilan pendampingan hukum. Lebih jauh lagi, pendampingan hukum ini dibutuhkan karena adanya permasalahan yang terus-menerus dihadapi buruh migran Indonesia sebagai dampak relasi sosial yang memarjinalisasikan mereka.

\section{METODE}

Pelatihan ini bermitra dengan para mantan buruh migran yang tergabung dalam Paguyuban SERUNI Banyumas, perangkat desa yang concern dengan permasalahan buruh migran danmahasiswa yang tergabung dalam Biro Konsultasi dan Bantuan Hukum Mahasiswa (Bikohuma) Universitas Jenderal Soedirman.Dalam pelatihan, metode yang digunakan dalam pelatihan ini adalah penyuluhan intensif selama 2 hari yang dilanjutkan dengan praktik di lapangan oleh para peserta pelatihan selama 5 bulan yaitu mendampingi kasus yang melibatkan BMI Banyumas.Pada bulan ke enam dan ke 7, dilakukan pertemuan untuk evaluasi praktek yang telah dilakukan.

\section{HASIL DAN PEMBAHASAN}

Kegiatan Pemberdayaan kepada masyarakat bermitra dengan Paguyuban SERUNI yang terletak di desa Datar, Kecamatan Sumbang. Dalam memnerima kasus butuh migran, Paguyuban SERUNI seringkali menerima pengaduan secara langsung. Namun tak jarang, Paguyuban SERUNI juga menerima pengaduan secara tak langsung yaitu melalui email dan akun media sosial (facebook).Sejak tahun 2012, Paguyuban Seruni memiliki website di www.seruni.or.id.yang berisi tentang informasi mengenai Paguyuban Seruni. Dalam website tersebut, Seruni membuat menu 'Kontak kami' dan juga mencantumkan alamat facebook sebagai media komunikasi antara seruni dan pembaca website.Media ini berfungsi untuk memberikan kesempatan kepada pembaca website untuk lebih mengenal dekat paguyuban seruni dan memperoleh informasi seputar buruh migran dan prosedur migrasi aman. Melalui website, Paguyuban Seruni menjalin hubungan dengan berbagai organiasai buruh migran atau perorangan di luar negeri yaitu di negara Singapur, Malaysia, Taiwan, Hongkong, Arab Saudi, Kuwait, Thailand dll. Mereka berjejaring untuk mengembangkan organisasi dan mencari 
informasi untuk mencari jalan keluar dari permasalahan buruh migran.

Pelatihan ini akan fokus pada permasalahan prioritas yang telah disinggung di latar belakang dan harus ditangani serta langkah-langkah solusi yang diambil dengan rincian yang terbagi menjadi tiga tahap, yaitu tahap awal berupa pemberian materi, dilanjutkan dengan praktik/pendampingan dan diakhiri dengan evalusi.

\section{Tahap pemberian materi}

Pelaksanaan pelatihan paralagel diikuti oleh para mantan buruh migran yang tergabung dalam Paguyuban Buruh Migran Seruni.Paguyuban Seruni adalah paguyuban untuk buruh migran yang diinisiasi oleh sekelompok mantan buruh migran yang berasal dari Banyumas.Sehingga pengurus organisasi dan anggota organisasi ini berasal dari buruh migran.Pada awalnya Paguyuban Buruh Migran Seruni bertujuan untuk membantu anggotanya dalam memberikan informasi terkait prosedur migrasi aman dan membantu menyelesaikan permasalahan yang dialami oleh anggota. Dalam perkembangannya, paguyuban SERUNI juga melakukan berbagaikegiatan lain, seperti ekonomi. Namun hal ini tidak menghilangkan tujuan awal dibentuknya Paguyuban SERUNI yaitu advokasi.Selain anggota Seruni, hadir dalam pelatihan adalah perangkat desa yang memiliki concern dengan persoalan buruh migran dan mahasiswayang tergabung dalam Biro Konsultasi dan Bantuan Hukum Mahasiswa (Bikohuma) Universitas Jenderal Soedirman.Perangkat desa yang hadir pada pelatihan ini berasal dari Desa Gumelar dan Desa Pamijen.Kedua desa ini memiliki jumlah buruh migran yang banyak dan sangat berpotensi dengan tingginya permasalahan buruh migran. Oleh karena itu, keberadaan perangkat desa sangat strategis untuk mendukung adanya paralegal yang akan membantu mereka bila warganya menjadi korban.
Dalam pelatihan tersebut diajarkan berbagai materi meliputi 1) Hak Asasi Manusia HAM yang berdasarkan Piagam HAM Universal.Sebagaimana yang telah diketahui, Indonesia telah meratifikasi UDHR. Hal ini berarti bahwa Indonesia wajib untuk melaksanakan ketentuanketentuanyang ada di UDHR; 2) Urgensi paralegal yang akan membantu para buruh migran yang mengalami masalah. Pada materi sesi ini dijelaskan tentang peta permasalahan BMI, terutamakondisi BMI yang terjadi di Kab. Banyumas; 3)Memahami alur proses hukum litigasi berdasarkan KUHAP. Hal ini penting bagi paralegal yang akan mendampingi korban. Mereka harus memahami tentang alur mengadukan kasus di pihak yang berwenang.Siapa saja yang harus ditemui untuk menyampaikan permasalahan.Apa saja yang harus dilakukan ketika berhadapan dengan pihak yang bersengketa. Hal ini akan memberikan modal ketenangan bagi paralegal ketika berhadapan dengan pihak kepolisian, kejaksanaan maupun dinas terkait. Seringkali sebagai orang awam akan merasa ketakutan ketika berhadapan dengan pihak berwenang; 4) jenis-jenis kasus dan bedah kasus. Pada sesi ini dijelaskan tentang pembuatan kronologi kasus yang dihadapi oleh paralegal; 5) materi tentang asuransi. Bagaimana mendapatkan asuransi.Apa saja yang dibutuhkan, dan berapa yang diterima oleh keluarga.Hal ini menjadi penting karena banyak kasus yang didampingi oleh mereka, terkait dengan asuransi; 6) materi tentang peraturan perundang-undangan yaitu UU no 39 tahun 2004. UU ini dibandingkan dengan Perda Perlindungan

Buruh Migran Kabupaten Banyumas No 2 tahun 2015. Secara general ,Perda lebih memberikan perlindungan yang menyeluruh terhadap BMI dan keluarga BMI. Oleh karena itu, setiap permasalahan yang dialami oleh BMI mendapat payung hukum peraturan, baik nasional maupun 
daerah; 7) teknik-teknik penanganan kasus.Siapa saja yang bisa dihubungi apabila menemui kasus.Bukan hanya di daerah, dalam level nasional, terdapat berbagai macam lembaga yang dapat dihubungi. Misalnya saja, Ombudsman RI, Komisi Informasi Pusat, Komisi Informasi Daerah, Lembaga Perlindungan Saksi, dll.Bahkan, jika mengalami hambatan udalam pendampingan, lembaga internasional dapat dihubungi untuk menyampaikan kasus tersebut.

Pada akhir pelatihan dibentuk grup whatsapp yang akan menjadi media komunikasi bagi paralegal. Aplikasi ini dinilai efektif karena hampir setiap paralegal memiliki handphone sehingga lebih mudah dan cepat dalam memberikan komunikasi.Grup ini juga merupakan sarana bersama untuk belajar antar paralegal tentang setiap kasus yang dihadapi.Selain itu disepakati adanyan rencana tindak lanjut yaitu dibentuk 3 (tiga) kelompok yang akan menangani kasus BMI. Adapun kelompok tersebut adalah :

Kelompok I, Kasus: Hilang kontak BMI asal Gumelar di Malaysia

Kelompok 2, Kasus: Hilang kontak BMI asal Kalikidang/ Sumbang di Malaysia

Kelompok 3, Kasus: Penahanan dokumen BMI asal Purwokerto oleh salah satu PPTKIS.

Kelompok-kelompok ini akan bertemu lagi pada bulan Okober 2017 untuk evaluasi

kasus dan hambatan-hambatan yang ditemui oleh paralegal.

\section{Tahap praktik}

Tahap praktik dilakukan selama 5 bulan.Masing-masing kelompok menjalankan tugasnya masingmasing.Kegiatan kelompok dimonitor via grup whatsapp.Dalam grup whatsapp ini, mereka saling berkomunikasi dan berkonsultasi tentang kasus masingmasing.

\section{Tahap Evaluasi}

Pada tahap ini dilakukan evaluasi terhadap kelompok hasil bentukan di tahap 1.Mereka menunjukkan kemajuan yaitu dengan laporan perkembangan kasus yang menjadi tugas pokok selama praktik.Satu kelompok hanya menunjukkan perkembangan yang sedikit.Hal ini berarti bahwa dari hasil pelatihan, sebanyak $70 \%$ peserta dapat menyerap materi dengan baik dan mampu menjadi paralegal seperti output yang diharapkan dari pelatihan.

Kelompok 1 melaporkan tentang perkembangan kasus tentang buruh migran yang hilang kontak asal Gumear di Malaysia.Mereka telah menghubungi pihak-pihak yang berkompeten untuk menanyakan hal tersebut.Walaupun kasus ini masih belum selsai, namun peserta pelatihan telah memahami dan mengerti alur pelaporan dan pengaduan serta mengontak pihak-pihak yang berwenag menangani kasus tersebut.

Kelompok 2 belum menunjukkan kemajuan yang signifikan dikarenakan keterbatasan alat transportasi dan juga daerah yang saling berjauhan.Hal ini menyebabkan mereka kesulitan untuk melakukan koordinasi dan pendampingan dan menyelesaikan kasusnya.

Kelompok 3 menunjukkan hasil yang sangat signifikan.Walaupun kasus masih berjalan, namun mereka telah

menghubungi keluarga dan phak-pihak yang berwenang.Mereka sangat semangat dan antusias dalam menyelesaikan kasus tersebut.Sebelum pelatihan, mereka belum menunjukkan ketertarikan untuk terjun sebagai paralegal, namun setelah pelatihan dan mendapatkan teman yang juga antusias, hal ini menyebabkan mereka juga menjadi antusias. Hal ini menjadi bukti 
bahwa pelatihan bukan hanya memberikan materi-materi terkait kasus, namun juga menyebarkan rasa semangat karena berjumpa dengan teman yang memiliki ktertarikan yang sama.

Dalam evaluasi ini, ditemukan beberapa hal, yaitu

1. Grup Whatapp yang dibentuk oleh paralegal dinilai efektif. Beberapa kasus di bagi lewat applikasi mobilephone dan paralegal merespon dengan cepat. namun, paralegal merasa perlu untuk melakukan koordinasi langsung antar anggota paralegal lewat pertemuan intensif yang dilaksanakan setiap bulan. Hal ini dirasakan karena beberapa anggota merasa kesulitan saat melakukan pendampingan akibat masih lemahnya kapasitas sebagai paralegal. Komunikasi di grup whatsapp dirasa kurang bebas sehingga pertemuan rutin yang akan diselenggarakan setiap bulan dapat membantu komunikasi antar paralegal. Pertemuan ini juga membantu mereka untuk saling berbagi pengetahuan dan keterampilan dalam proses pendampingan. Dalam pertemuan rutin tersebut, setiap paralegal akan bertukar pikiran dan berdiskusi tentang kasus dampingan masing-masing. Pertemuan ini sebenarnya secara tidak langsung memberikan manfaat terhadap Paguyuban Seruni sebagai organisasi induk paralegal untuk menjadi paguyuban yang kuat karena anggotanya semakin solid.

2. Dibutuhkan wadah resmi untuk memperkuat komitmen anggota paralegal dalam menyelesaikan permasalahan buruh migran. Wadah ini sebagai induk organisasi yang akan memayungi paralegal dalam beraktifitas. Pertemuan tersebut menyepakati bahwa paralegal hasil pelatihan akan berada dibawah koordinasi Divisi Advokasi Paguyuban SERUNI.

3. Organiasi dapat berjalan jika terdapat dana yang akan menunjang kegiatan mereka. Oleh karena itu, dalam pertemuan tersebut, muncul ide untuk membentuk kelompok usaha bersama yang akan membantu perekonomian serta untuk menunjang operasional organisasi. Selama ini, paralegal Paguyuban Seruni adalah sebuah kegiatan sukarela yang tidak mendapat imbalan Padahal di satu sisi, kegiatan operasional sangat membutuhkan biaya.Oleh karena itu, untuk menunjang kegiatan operasional, maka usaha bersama dipandang sebagai salah satu solusi untuk mengatasi permasalahan tersebut. Oleh karena itu muncul wacana untuk membuat usaha bersama.

4. Paralegal akan melakukan sosialisasi yaitu dengan pembuatan poster migrasi aman yang dipasang di masing-masing kantor desa. Di dalam poster tersebut terdapat kontak paralegal. Poster ini selain sebagai media sosialisasi tentang migrasi aman, juga sebagai media untuk mengenalkan kepada masyarakat tentang keberadaan paralegal yang concern menangani kasus BMI.

5. Pembuatan tanda pengenal paralegal Paguyuban Seruni. Kartu pengenal ini digunakan paralegal ketika bertugas di dinas-dinas dan juga di instansi lain. Kartu pengenal ini juga sebagai kartu identitas resmi paralegal dari Paguyuban Seruni.

6. Penguatan kapasitas paralegal mengenai hukum di negara tujuan migrasi. Penguatan ini dilakukan dengan memberikan pengetahuan hukum kepada paralegal yang akan diberikan oleh tim dan juga dengan pihak-pihak yang sepakat untuk bekerjasama dengan tim pengabdian kepada masyarakat. 
7. Pelatihan penulisan kasus yang sedang ditangani. dalam evaluasi ini, terungkap bahwa ada beberapa paralegal yang masih harus terus dilatih untuk menulis kasus yang runtut dan jelas sehingga kronologi kasus tersbut akan membantu mereka untuk melakukan tahap pendampingan selanjutnya.

8. Pembuatan draft Naskah Perjanjian Kerjasama yang akan melibatkan Pusat Penelitian Gender, Anak dan Pelayanan Masyarakat (PPGA-PM) Universitas Jenderal Soedirman, Paguyuban Buruh Migran Seruni dan Fakultas Hukum Universitas Jenderal Soedirman. Naskah Perjanjian Kerjasama ini akan menjadi payung hukum untuk melakukan kegiatan-kegiatan yang terkait dengan isu buruh migran yang melibatkan ketiga pihak tersebut. Adapun kegiatan tersebut meliputi : pendampingan hukum kepada buruh migran baik litigasi maupun non litigasi, penyuluhan hukum dan pelatihan hukum.

\section{SIMPULAN}

Program pelatihan paralegal buruh migran Banyumas ini telah berhasil mendorong kelompok buruh migran sebagai bagian dari civil society untuk melakukan pendampingan bagi BMI asal Banyumas yang sedang terlibat masalah.Tidak hanya itu, mereka kemudian meningkatkan koordinasi antar personel dengan rencana tindak lanjut berupa pertemuan rutin bulanan untuk update dan diskusi penanganan kasus. Pendampingan hukum juga akan terus ditingkatkan melalui pendekatan yang lebih preventif yakni pendidikan bagi aparat desa dan masyarakat mengenai prosedur migrasi aman di negara tujuan. Pencapaian ini didapatkan karena program pelatihan paralegal telah diikuti dengan pemantauan pelaksanaan tindak lanjut dan pendampingan koordinasi antar paralegal.

\section{DAFTAR PUSTAKA}

Edwards, M. (2009). Civil society. Cambridge: Polity.

Kunreuther, F. (2011)."'Grassroot Associations", dalam Edwards, M. (Ed.).(2013). The Oxford handbook of civil society. Oxford: Oxford University Press.

Mayo, M. (2005).Global citizens: Social movements and the challenge of globalization.Zed Books.

Nusantara, G. A. W. (2016). 'Eksistensi Paralegal Dalam Mengoptimalkan Pemberian Bantuan Hukum Berdasarkan Undang-Undang No. 16 Tahun 2011 Tentang Bantuan Hukum', Udayana Master Law Journal, 5(2), 272-280.

Wijayanti, S., Zayzda, N.A., dan Yamin, M. (2016).Optimalisasi Teknologi Informasi Sebagai Strategi Penanganan Kasus Buruh Migran Indonesia Di Luar Negeri, Laporan Penelitin, LPPM Unsoed 